\title{
Immunomodulatory Properties of Host Defence Peptides in Skin Wound Healing
}

\author{
Marija Petkovic (D), Michelle Vang Mouritzen (D), Biljana Mojsoska (D) and Håvard Jenssen *(D) \\ Department of Science and Environment, Roskilde University, 4000 Roskilde, Denmark; marijap@ruc.dk (M.P.); \\ mvang@ruc.dk (M.V.M.); biljana@ruc.dk (B.M.) \\ * Correspondence: jenssen@ruc.dk; Tel.: +45-4674-2877
}

check for

updates

Citation: Petkovic, M.; Mouritzen, M.V.; Mojsoska, B.; Jenssen, H. Immunomodulatory Properties of Host Defence Peptides in Skin Wound Healing. Biomolecules 2021, 11, 952. https://doi.org/10.3390/ biom11070952

Academic Editors: Ryan Moseley,

Robert Steadman and Adam

C. Midgley

Received: 1 June 2021

Accepted: 19 June 2021

Published: 28 June 2021

Publisher's Note: MDPI stays neutral with regard to jurisdictional claims in published maps and institutional affiliations.

Copyright: (c) 2021 by the authors. Licensee MDPI, Basel, Switzerland. This article is an open access article distributed under the terms and conditions of the Creative Commons Attribution (CC BY) license (https:/ / creativecommons.org/licenses/by/ $4.0 /)$.

\begin{abstract}
Cutaneous wound healing is a vital biological process that aids skin regeneration upon injury. Wound healing failure results from persistent inflammatory conditions observed in diabetes, or autoimmune diseases like psoriasis. Chronic wounds are incurable due to factors like poor oxygenation, aberrant function of peripheral sensory nervature, inadequate nutrients and blood tissue supply. The most significant hallmark of chronic wounds is heavily aberrant immune skin function. The immune response in humans relies on a large network of signalling molecules and their interactions. Research studies have reported on the dual role of host defence peptides (HDPs), which are also often called antimicrobial peptides (AMPs). Their duality reflects their potential for acting as antibacterial peptides, and as immunodulators that assist in modulating several biological signalling pathways related to processes such as wound healing, autoimmune disease, and others. HDPs may differentially control gene regulation and alter the behaviour of epithelial and immune cells, resulting in modulation of immune responses. In this review, we shed light on the understanding and most recent advances related to molecular mechanisms and immune modulatory features of host defence peptides in human skin wound healing. Understanding their functional role in skin immunity may further inspire topical treatments for chronic wounds.
\end{abstract}

Keywords: antimicrobial peptides; host defence peptides; chronic wounds; skin wound healing; inflammation; skin immune response

\section{Introduction}

Acute wounds in diabetic patients can adopt and portray the chronicity of the nonhealing wounds due to bottom-line complications like the duration of diabetes or vascular disease paired with peripheral neuropathies [1]. Wounds that do not heal naturally within three months are defined as chronic wounds, and often require treatment to heal. Wounds that have healing difficulties are subcategorised into four aetiology categories: venous, pressure, diabetic and arterial insufficient ulcers. Non-healing wounds share a lack of oxygen and nutrient supply and microbial contagion, delaying the wound from healing [2]. Diabetic foot ulcerations occur in about $20 \%$ of the diabetic population, being prevalent among the chronic wound aetiologies, like venous and pressure ulcers [3].

Other inflammatory skin conditions like psoriasis [4,5] and atopic dermatitis [6] are also characterised by dysregulation of the immune response, attacking healthy skin cells.

Host defence peptides are polycationic peptides exhibiting various antimicrobial activities or prompting the host's immune responses. These agents are naturally produced by a wide variety of species, ranging from marine organisms to humans. Recent studies propose the dual importance of host defence peptides (HDPs) in the different phases of wound healing $[7,8]$. As the first line of defence against pathogenic bacterial infection, HDPs are a critical element in preventing biofilm-associated infections [9,10]. A decline in sufficiently effective antibiotic treatments due to growing problems with antibiotic resistance may be ameliorated with alternatives to conventional antibiotics like peptides 
with antimicrobial properties [11]. Aside from bacterial pathogen inactivation by disrupting their cell membranes, host defence peptides also have immunomodulatory properties, due to their ability to stimulate the cross-talk between immune cells promoting cutaneous wound healing in a healthier manner [12].

Different HDPs share some similarities like the number of amino acid residues being between 10 and 60, a cationic charge of 2-9 and depending on the sequence length, HDPs are classified as long (50-100 amino acids), intermediate (25-50 amino acids) or short (9-24 amino acids) $[13,14]$. The diverse structure yet positive net charge that they have in common is an important prerequisite for the design of the more stable, synthetic analogues that interact with anionic prokaryotic membranes: lipopolysaccharides (LPS; in Gram-negative bacteria) and teichoic acids (in Gram-positive bacteria) [11]. Host defence peptides and their synthetic analogues called peptidomimetics, which contain sequences built by natural and unnatural amino acids [15]. These building blocks determine the signature physiochemical properties, which are the charge (neutral or positive) and the hydrophobicity /hydrophilicity. These in turn contribute to the other level of structural complexity that plays a significant role in the activity: the secondary structures of HDPs $[16,17]$. Aside from their known potential for evading infections, an increasing body of evidence has demonstrated that HDPs are able to exert intracellular inhibitory activities as the primary or supportive mechanisms to achieve efficient killing [18]. The latter activity is referred to as immunomodulatory activity, and multiple studies have presented evidence on this important role in innate and adaptive immune response [19]. Most of the HDP derivatives include a combination of microbicidal action and immunomodulatory functions [20]. The challenges associated with creating a non-immunogenic peptide without the potentially adverse effects observed in natural HDPs may be defeated by the modification of internal sequences or single amino acid substitutions [21,22]. An example of such peptides is innate defence regulator peptides (IDR peptides) [23,24]. Specific signature structure properties that allow synthetic peptides to exert immunomodulatory properties are yet not well defined in the literature and are quite diverse.

\section{Host Defence Peptides in Wound Healing}

Cationic peptides play a primarily role in maintaining the skin barrier's integrity and cutaneous tissue restoration during injury [25]. Due to expanding the effects of antimicrobial peptides on bacteria, HDP have been assigned the fundamental biological role in innate immunity [26]. Due to their lack of adaptive immune systems, arthropods and plants rely on their HDPs' primary defence response [27,28]. In higher eukaryotes, the levels of the host's defence peptides patrolling through signalling networks of the immune response are significantly more abundant, as their multifaceted role is more complex [29].

Skin resident HDPs are crucial participants of each step of the wound healing process: inflammation (neutrophil and macrophage infiltration), wound site regeneration (angiogenesis and re-epithelialization) and remodelling (restoration of tensile strength) $[25,30]$.

In humans, two main classes of host defence peptides have been identified: defensins and cathelicidins (Figure 1). However, there are also a variety of other small peptides expressed by epithelial cells like Substance P [31], neurotensin [32], granulysin [33], calprotectin [34], adrenomedullin [35], MRP8/MRP-14 [36] and RNase A superfamily [37], which are also important wound inflammatory biomarkers. 

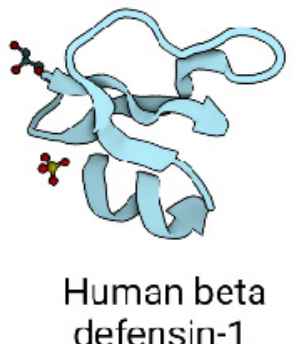

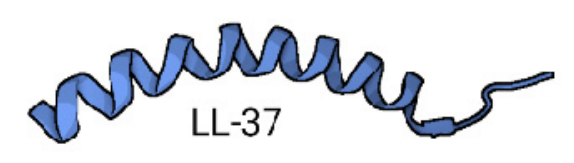

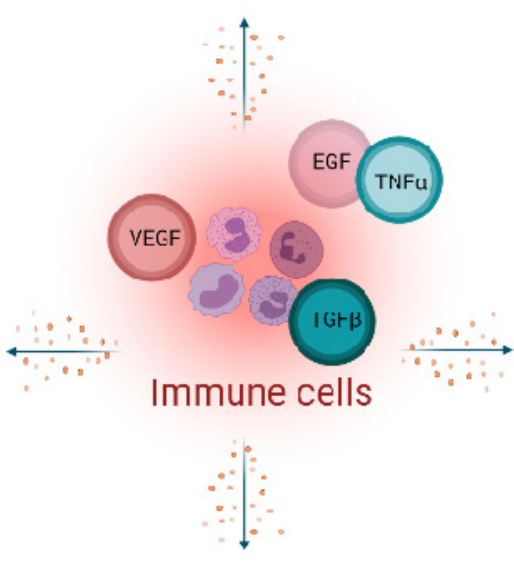

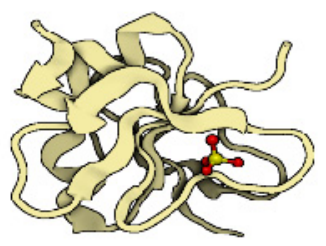

Human beta

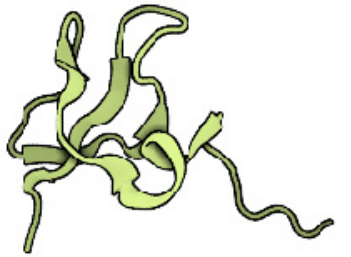

Human beta defensin-3

Figure 1. Host defence peptides expressed by skin cells are induced by immune response, and act via signalling proteins belonging to growth factors like Vascular Endothelial Growth Factor (VEGF), Transforming Growth Factor beta (TGF $\beta$ ), Epidermal Growth Factor (EGF) and cytokines like Tumor Necrosis factor alpha $(\mathrm{TNF} \alpha)$. Immune cells produce LL-37 from the cathelicidin family (Pdb code: 2K6O) [10] and defensin family: Human defensin 1 (Pdb code: 1IJU) [38], Human defensin 2 (Pdb code: 1FD4) [39], Human defensin 3 (Pdb code: 1KJ6) [40].

\subsection{Defensins}

Peptides from the defensin family are small peptides that are widely distributed across species, including humans. Human defensins (HDs) are produced in leukocytes and are also secreted by different epithelial cells and mucosal tissues [38]. The mature defensins are described as short (28-42 amino acids length), cationic (net charge +1 to +11 ), amphipathic peptides with a highly conserved tertiary structure of a triple antiparallel $\beta$-sheet fold arrangement accommodating the six cysteine residues connected with three disulphide bridges [39].

Moreover, depending on the size, location, spatial conformation, and spot where the cysteines lay within the peptide chains, they are categorised as $\alpha$-defensins, $\beta$-defensins and $\theta$-defensins $[39,40]$. In humans, only $\alpha$ and $\beta$-defensins are present, while structurally different, cyclic $\theta$-defensins have been identified in rhesus macaques $[39,41]$.

Additionally, the HDs have antimicrobial activity against various strains of Gram-positive and negative bacteria [42], fungi [43] and viruses such as the herpes simplex virus [44].

In humans, there are $6 \alpha$-defensins: HNPs1-4 and human $\alpha$-defensins 5 and 6 (HD5 and HD6) [42,45]. HNPs 1-3 (human neutrophil peptides) differ by single amino acid substitutions and are predominantly produced by neutrophils.

Moreover, $\beta$-defensins abundance is tightly governed by transcriptional controls assigned to epithelial and epidermal cells [46]. One representative of the $\beta$-defensin family such as human $\beta$-defensin 1 (HBD1) is continuously transcribed in skin cells, while the transcription of human $\beta$-defensin 2 (HBD2) and human $\beta$-defensin 3 (HBD3) as the others is triggered in response to a microbial or pro-inflammatory cytokines presence [47]. 


\subsection{Cathelicidins}

Endogenous cathelicidins are stored at high concentrations as inactive precursors in granules of mammalian neutrophils and mast cells. In contrast to defensins, cathelicidins are predominantly $\alpha$-helical, amphipathic, cationic (possessing a net positive charge of 2-9) and consist of 23-37 amino acids [48].

Cathelicidins are named after the conserved cathelin-like domain, and are produced as protein precursors, containing a conserved amino-terminal ( $\mathrm{N}$-terminal) signal peptide domain, an antimicrobial C-terminal domain mature peptide and cathelin-like domain [49].

The active form of peptide is formed once the cathelin domain is cleaved by serine proteases upon neutrophils degranulation and secretion of peptides [50].

The gene for hCAP-18, named CAMP, encodes the human cathelicidin. LL-37, the only member of the cathelicidin family identified so far in humans, is present in the secondary (specific) granules of neutrophils, macrophages, and epithelial cells [51]. Human cathelicidin hCAP-18, is processed by proteinases into several extracellular cleavage products, with LL-37 being one of them [52]. Cathelicidins play an important regulatory role in the inflammatory response [53]. Many studies support immunomodulatory actions over the antimicrobial actions of cathelicidins [26,48]. However, the constitutive generation of the cathelicidins across the various species provides them with strong antimicrobial protection from bacteria [54], viruses [55] or fungi [56].

\section{Wound Healing Phases}

The skin is a multifunctional organ whose outermost position provides protective a barrier [57]. In addition to providing mechanical protection and support to internal organs, the subtle cutaneous microenvironment has the capacity to actively mediate immune response [58]. The intact skin is composed of three layers: epidermis, dermis and hypodermis, with the epidermis being the outermost layer and the hypodermis the innermost layer.

When a wound occurs in the skin, healing is essential for the skin to restore the integrity. The wound healing is a perplexed process consisting of three sophistically coordinated phases: inflammation, proliferation, and remodelling [59]. However, this classification is arbitrary, as those phases are overlapping, and even distant areas of wounds can be in different phases of healing [60] (Figure 2).

\subsection{Inflammation}

The inflammatory phase begins with hemostasis. Hemostasis involves various protease cascades leading to the formation of a fibrin cloth to prevent blood loss and seal the wound [61]. The inflammatory phase is characterised by infiltration of immune cells, such as neutrophils, macrophages, and lymphocytes, which aim to eliminate pathogens and cellular debris from the wound site [62].

Neutrophils as the first responders engulf the pro-inflammatory cytokines, with DNA, RNA and other cellular components often referred to as damage-associated molecule patterns [63]. Phagocytic products trigger the release of cytokines, growth factors, production of reactive oxygen species (ROS) and proteolytic enzymes, which in turn attract more immune cells to the wounded site [64]. Another highly abundant subpopulation of immune cells are macrophages. During wound healing, two subgroups of macrophages populate the wound depending on the cytokine secretion profile: pro-inflammatory or M1 and anti-inflammatory or M2 [65]. The macrophage polarisation to either the pro- or anti-inflammatory phenotype is tightly controlled by signalling pathways, transcriptional and posttranscriptional regulatory networks [66]. 


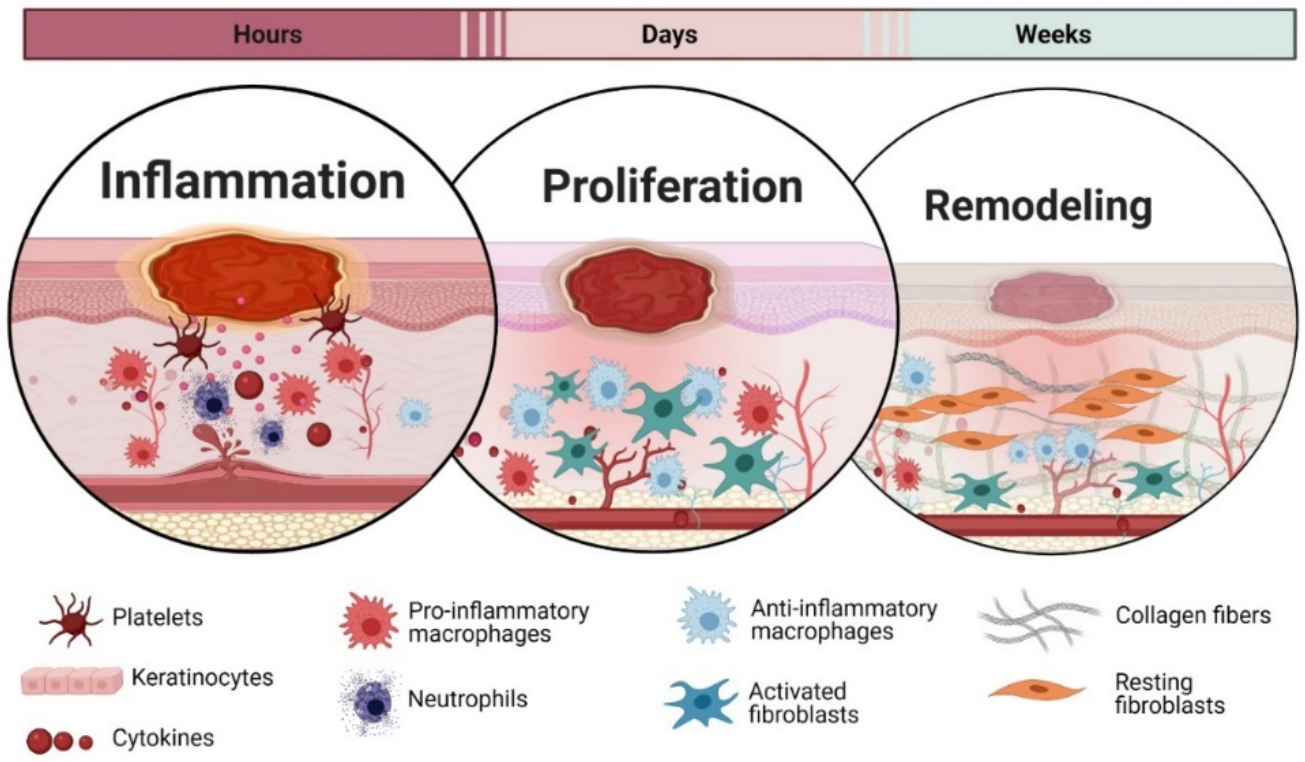

Figure 2. Wound healing phases. The timeline and overview for the healing phases also shows the involvement of the key cellular populations involved in the different phases.

\subsection{Proliferation}

The proliferative phase is characterised by re-epithelialization, angiogenesis and formation of granulation tissue that leads to closure of the epithelial layer, revascularization in the damaged area and tissue regeneration [67].

Epidermal growth factor (EGF) release initiates the re-epithelialization of the epidermis. This stimulates the keratinocytes, as the predominant cell type in the epidermis, to protrude, adhere, contract, and detach, migrating this way under the fibrin clot [68]. Angiogenesis is the formation of new blood capillaries existing from vessels. This is crucial, as healing requires energy for cell proliferation, migration, and production of collagen. Angiogenesis is stimulated by vascular endothelial growth factor (VEGF) [69]. The granulation tissue restoration formation is necessary for the connective tissue restoration, and it is performed by fibroblasts that synthesize the extracellular matrix (ECM) and collagen to strengthen the new tissue [70].

\subsection{Remodelling}

The remodelling phase can span for several years [71]. The remodelling or maturation phase involves degradation of the ECM and collagen III to collagen I replacement, resulting in increased tensile strength of the newly formed tissue [72,73]. The fibroblasts differentiation into myofibroblasts aids reduction of the wound size. Once the contraction of the wound is completed, the number of immune cells [74], the vessels [75] and the myofibroblasts undergo apoptosis [76]. The newly formed fibres and collagen structures are disorganised and can take years before they are properly reorganised to form fully healed tissue [77].

\section{Cellular Regulation and Immunomodulatory Actions of Host Defence Peptides during Wound Healing}

Factors affecting wound healing can be categorised into systemic and local factors. Systemic factors are present at all times in the individual, as seen in diseases such as diabetes, stress, obesity and age, while local factors include factors, such as infection, oxygenation and foreign bodies, which directly influence the wound locally [78]. The local factors lead to high levels of pro-inflammatory cytokines and ROS, impaired cell and protease function and a lack of growth factors [79]. HDPs have been demonstrated to influence many local 
factors, such as regulating expression of cytokines [80], chemokines [81], proteases [82], growth factors [83] and immune cell activity [84-86] (Table 1).

Table 1. Host defence peptides immunomodulatory actions in wound healing phases.

\begin{tabular}{|c|c|c|}
\hline $\begin{array}{l}\text { Human Host Defence } \\
\text { Peptide }\end{array}$ & Immunomodulatory Action & Reference \\
\hline \multicolumn{3}{|c|}{ Inflammatory phase } \\
\hline \multirow{4}{*}{ LL-37 } & $\begin{array}{l}\text { Cell migration mediated by } \\
\text { EGFR and ERK } 1 / 2\end{array}$ & [87] \\
\hline & Recruitment of leukocytes & [88] \\
\hline & $\begin{array}{l}\text { Secretion of anti-inflammatory } \\
\text { cytokines like IL-1RA }\end{array}$ & [89] \\
\hline & $\begin{array}{l}\text { Enhanced SMAD2/3 and } \\
\text { STAT3 phosphorylation }\end{array}$ & [90] \\
\hline LL-37, hBD-2, hBD-3, hBD-4 & $\begin{array}{l}\text { Activation of the p38 and } \\
\text { ERK1/2 MAPK pathways }\end{array}$ & [91] \\
\hline hBD-2, hBD-3 & $\begin{array}{l}\text { Activate plasmacytoid } \\
\text { dendritic cells (pDCs) }\end{array}$ & [92] \\
\hline S100A7 & $\begin{array}{c}\text { Increased } \\
\mathrm{NF \kappa B} / \mathrm{p} 38 \mathrm{MAPK} / \text { Caspase- } \\
\text { 1/IL-1a } \\
\text { signalling }\end{array}$ & [93] \\
\hline \multicolumn{3}{|c|}{ Proliferative phase } \\
\hline LL-37 & $\begin{array}{l}\text { Induction of growth factors } \\
\text { such as EGF and VEGF }\end{array}$ & {$[87]$} \\
\hline & Neovascularization & [94] \\
\hline hBD-2, hBD-3 & $\begin{array}{l}\text { Keratinocyte migration and } \\
\text { proliferation }\end{array}$ & [95] \\
\hline \multicolumn{3}{|c|}{ Remodelling phase } \\
\hline LL-37 & $\begin{array}{c}\text { Polarisation to M1 } \\
\text { macrophages }\end{array}$ & [53] \\
\hline Cathelicidin-WA (CWA) & $\begin{array}{l}\text { Suppressed phosphorylation } \\
\text { of STAT1 and NF-kB, } \\
\text { repressed phosphorylation of } \\
\text { STAT6 }\end{array}$ & [96] \\
\hline S100A7 & $\begin{array}{c}\text { Aberrant response of } \\
\text { fibroblasts and endothelial } \\
\text { cells }\end{array}$ & [97] \\
\hline
\end{tabular}

\subsection{Host Defense Peptides Triggered by Inflammation}

Many acute and chronic inflammatory disorders have been correlated with dysregulation of the natural HDP response [26,98]. Although the reciprocity of either deficiency or overproduction of HDPs in the presence of inflammation and thus balance between pro- or anti-inflammatory effects is not so easy to define directly, this can lead to a pathological inflammatory response $[99,100]$. Endogenous host defence peptides, stored intracellularly at high concentrations as inactive precursors in granules, are released locally at infection and inflammation sites, whereas the expression of others is induced in response to pathogen-associated molecules [101].

The role of the immune cells in the inflammatory phase is intended to eliminate intracellular pathogens, and this is achieved by producing host defence peptides, which in turn promote the robust recruitment of immune cells such as neutrophils, monocytes/macrophages, dendritic cells, and T cells [26]. Altered levels of either pro- [102,103] or anti-inflammatory $[81,104,105]$ cytokines have been reported in inflammatory condi- 
tions. A persistent inflammatory environment has been demonstrated to affect not only the function of immune cells [106], but also the composition of the host defence peptides detected at the wound site [107] (Figure 3).

Defensins and cathelicidins family members have distinct roles in various disease states, and many studies support the potential synergistic roles of defensins and cathelicidins in cytokines chemoattraction in skin immune responses [91]. Tightly coordinated actions of hBD-2, -3 and -4 along with LL-37 induce secretion of IL-18 by keratinocytes through activation of the p38 and ERK1/2 MAPK pathways [91]. Under inflammatory skin conditions, high expression levels of keratinocyte hBD-2 induced by IL-17A and TNF $\alpha$ indicate that it may be considered as a marker for disease severity [108].

Inflammatory skin conditions like psoriasis are linked to elevated levels of both IL-1a and S100A7 (also known as psoriasin) and an increased signalling axis composed of NFкB/p38MAPK/Caspase-1/IL-1a, which regulates S100A7 [93]. Moreover, the increased expression of LL-37 is associated with overproduction of IFN $\gamma$ in psoriatic lesions, while hBD-2, hBD-3 and lysozyme can activate plasmacytoid dendritic cells (pDCs) in co-action with LL-37 [92]. LL-37 evokes pro-inflammatory chemotaxis through binding to the formyl peptide-like receptor-2 (Fpr-2), a cell sensing element for microbial products [88]. The human host defence peptide LL-37 binds to these $G$ protein-coupled receptors and activates mucosal immune response through recruitment of leukocytes [88]. In contrast, LL-37 can mediate anti-inflammatory responses such as secretion of anti-inflammatory cytokines like IL-1RA [89]. Another prominent feature of the neutrophil released cathelicidins is enhanced SMAD2/3 and STAT3 phosphorylation in the presence of transforming growth factor- $\beta$ (TGF $\beta$ ), shifting the T-cells subset towards Th17 rather than the Th1 phenotype, resulting in Th17 but not Th1 cells protection from apoptosis [90].

Atopic dermatitis (eczema) is another pathological skin condition [109]. Unlike the psoriasis which is characterised by elevated levels of innate immunity peptides, in atopic dermatitis, host defence peptide levels are not abundant and together with skin dryness make affected areas prone to infections [110].

\subsection{Host Defense Peptides Involved in Proliferative Phase of Wound Healing}

It has been shown that LL-37 peptide induces growth factors, such as EGF and VEGF, but also binds their receptors $[87,111]$. Aberrant vascularization during wound restoration in mice lacking the CRAMP (the murine homologue of LL-37/hCAP-18), shows that the peptide can stimulate endothelial cells, increasing the proliferation rate and thus enhancing the dermal neovascularization [94].

Furthermore, high levels of hBD-2 and hBD-3 detected at wound sites promote keratinocyte migration and proliferation, indicating their involvement in the re-epithelialization of the healing epithelium $[95,112]$. A relatively recent study demonstrated that topical insulin delivery to the wound enhanced the levels of extracellular-signal regulated kinase (ERK) and protein kinase B (Akt) [113]. ERK is a part of a phosphorylation pathway that activates gene transcription leading to cell $[114,115]$ and increased Akt stimulated angiogenesis through activation VEGF signalling [116,117] (Figure 4).

\subsection{Host Defense Peptides in Tissue Remodelling Phase}

The direction of macrophages polarisation into relevant phenotypes during different phases of wound healing (i.e., polarisation to a pro-inflammatory phenotype during the inflammatory phase and anti-inflammatory phenotype during the subsequent proliferation and remodelling phase) $[118,119]$ is controlled by many factors, while different HDPs (like LL-37) promote polarisation to M1 macrophages [53]. Similarly, elevated levels of interleukin-6 (IL-6), IL-1 $\beta$, tumour necrosis factor- $\alpha$ (TNF $\alpha)$ and chemokine CCL3 in RAW264.7 cells can be dampened by Cathelicidin-WA (CWA) [96]. CWA peptide suppresses the expression of TLR-4 and the phosphorylation of STAT1 and NF- $\mathrm{B}$, downregulating the activity of pro-inflammatory macrophages while stimulating the phosphorylation of STAT6 and activating E. coli K88-induced anti-inflammatory macrophages [96]. 

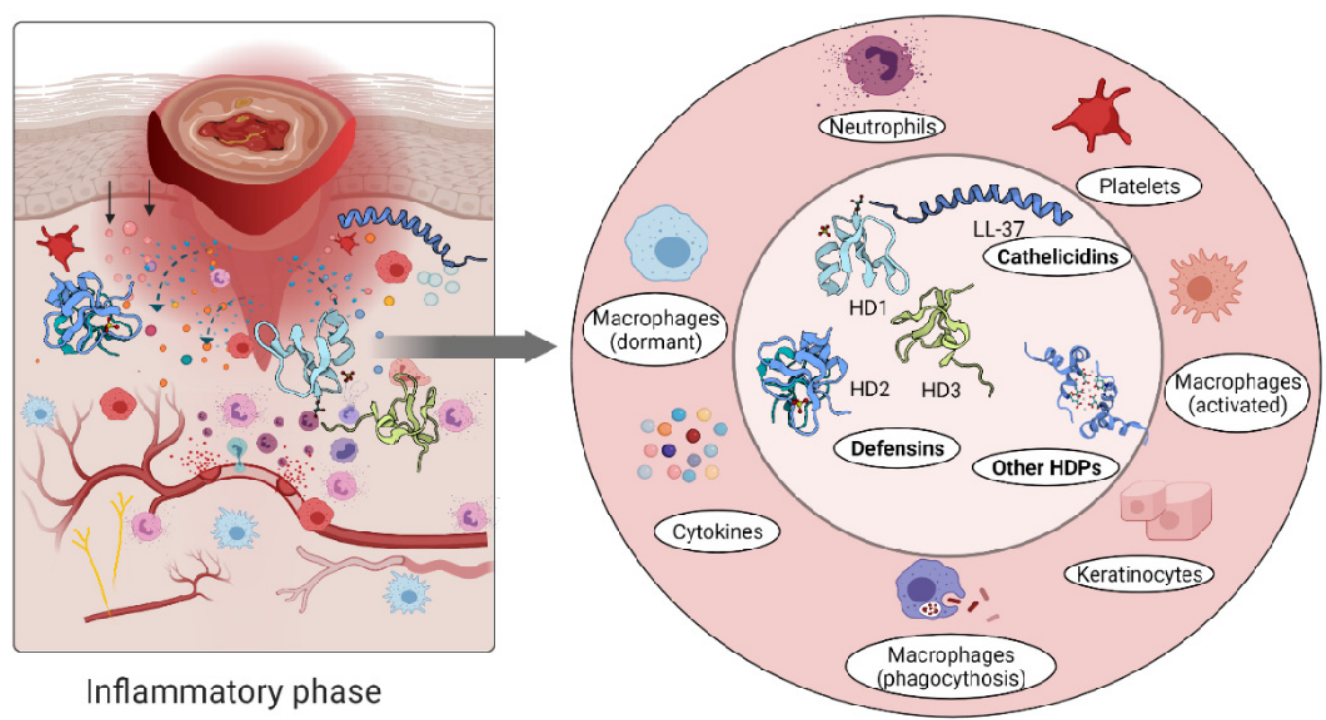

Figure 3. Immune response triggers skin cells to secrete host defence peptides. The secreted peptides are involved in antibacterial killing but also the recruitment of other immune cells to the wounded area.

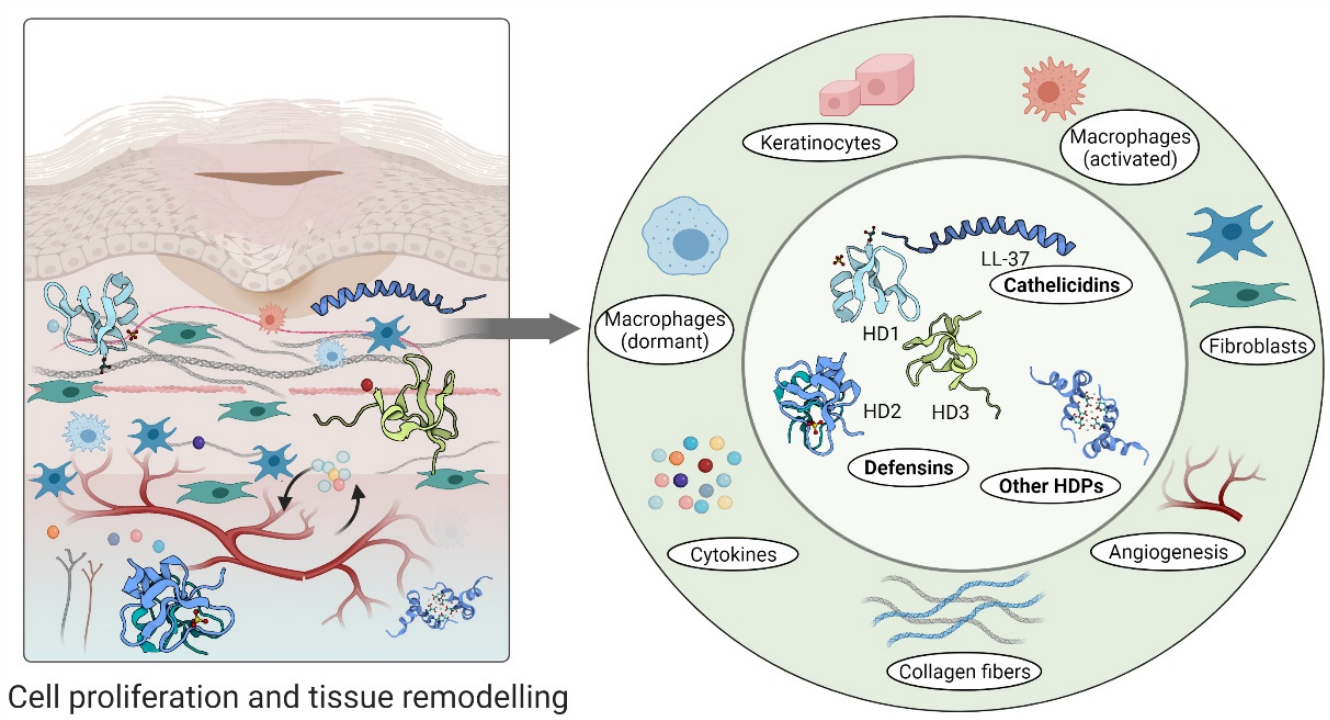

Figure 4. Host defence peptides involved in later stages of wound healing to assist skin regeneration.

An aberrant response described as overgrowth of fibroblasts and endothelial cells may be due to high concentrations of psoriasin in wound fluid and granulation tissue [97]. Psoriasin stimulates the tissue remodelling by inhibiting the excessive production of collagen, fibronectin and TGF $\beta$ formation in fibroblasts. In keloid-derived fibroblasts, psoriasin production is decreased [97] (Figure 4).

\section{Immunomodulatory Host Defence-Inspired Peptide Wound Treatments}

Many host defence-inspired peptides are used as topical dermal treatments for wound healing [25], and the list of experimentally verified alternatives peptides is long [24,120124]. One of the most widely used peptides for wounds with healing impairments and infections is LL-37 [125-130]. Transdermal delivery of peptides may be enhanced using novel 3D nanofiber scaffolds, to overcome previously reported poor cellular penetration [125]. The $\mathrm{CO}_{2}$ expanded nanofiber scaffolds can greatly promote cellular infiltration, neovascularization, and positive host response after subcutaneous implantation of coated LL-37 peptide [125]. Nanoparticles lipid carriers (NLCs) encapsulating LL-37 and administered 
through the topical route, have demonstrated to accelerated wound closure along with re-epithelization and decreased the inflammation in vitro and in vivo [126]. Moreover, the topical administration of LL-37 encapsulated in PLGA nanoparticles accelerated the wound closure along with re-epithelialization and improved the structure of the granulation tissue at the wound bed [127]. In addition to this, significantly up-regulated IL-6 and VEGF expression modulated the inflammatory wound response, leading to neovascularization improvements [127].

LL-37-conjugated gold nanoparticles exhibited enhanced in vivo wound healing activity compared to LL-37 alone by improving cell migration mediated by EGFR and ERK1/2 phosphorylation [131]. Wounds treated with LL-37-conjugated gold nanoparticles exhibited a better structure of collagen fibres IL-6 and VEGF [131]. Chronic diabetic wounds treated with antimicrobial peptide (LL-37) and fused with ultra-small gold nanoparticles (AuNPs) as a gene delivery system supported accelerated wound closure, as the wounds were permeated with newly formed blood vessels and the bacterial load was reduced [128]. In addition to, faster re-epithelization, granulation tissue improved, and VEGF expression increased [128]. LL-37 inspired wound drugs offer efficiency but require delivery stability through artificially synthesized carriers like calcium phosphate CaP nanoparticles [129]. Coating the LL-37 on CaP offers protection against enzymatic degradation, while the biological functionality and antimicrobial activity against both Gram-positive and Gram-negative bacteria remains intact [129].

Another wound healing therapeutics inspired by human $\alpha$-defensin 5 (HD5) is nanodefensin (ND) with dual antimicrobial/immunomodulatory action [130]. The coating with upgraded pharmacological stability, a nanodefensin-encased hydrogel (NDEFgel) locally applied to the wounded surface, accelerated wound regeneration, and increased the expression of myofibroblasts and GTP-binding protein Rac1 [130].

Neuropeptides released from peripheral nerves like neurotensin display amelioration of wound healing impairments when loaded on collagen dressings by reducing the inflammation in diabetic mice wounds [132]. Exogenous delivery of the neurotensin does not translate into functional modifications on keratinocytes, particularly in terms of migration $[117,133]$. Another peptide with relevance to wound healing is Substance P, an undecapeptide (11 amino acids long) member of the tachykinin neuropeptide family [134]. Its effects are exerted via a high-affinity neurokinin-1 receptor (NK1R), and NK1RKO mice show higher Substance P expression [135]. The local treatment with Substance P or analogues has the potential not only to promote diabetic foot ulceration healing but also to modulate inflammation and macrophage phenotype $[117,135]$. An injectable Laponite nanodiscs-based hydrogel loaded with Substance P promoted wound healing by delivering the Substance P to a tissue-engineered skin model to stimulate the reepithelialization process [136].

\section{Conclusions and Perspectives}

HDPs are a vital component of the innate immune system of all eukaryotic organisms. In addition to their ability to kill microbial pathogens directly, HDPs can indirectly modulate the host defence systems. Dysregulation of their expression not only in the skin, but also in other body sites, can contribute to various pathological states. There are increasing efforts to further characterize peptide interactions with the immune system of various novel human HDPs as well as synthetic analogues and increase our knowledge of their role in wound healing. Their immunomodulation activity is promising for the development of effective drug adjuvants and antimicrobial therapeutics.

Author Contributions: Writing—original draft preparation, M.P.; writing—review and editing: M.P., M.V.M., B.M. and H.J. All authors have read and agreed to the published version of the manuscript.

Funding: M.V.M and H.J. were funded by the Danish Council for Independent Research, Technology and Production, Grant 4005-00029.

Institutional Review Board Statement: Not applicable. 
Informed Consent Statement: Not applicable.

Acknowledgments: Figures were created with BioRender (Biorender.com, accessed on 27 June 2021).

Conflicts of Interest: The authors declare no conflict of interest.

\section{References}

1. Groppa, E.; Colliva, A.; Vuerich, R.; Kocijan, T.; Zacchigna, S. Immune cell therapies to improve regeneration and revascularization of non-healing wounds. Int. J. Mol. Sci. 2020, 21, 5235. [CrossRef]

2. Calis, H.; Sengul, S.; Guler, Y.; Karabulut, Z. Non-healing wounds: Can it take different diagnosis? Int. Wound J. 2020, 17, 443-448. [CrossRef]

3. Davis, F.M.; Kimball, A.; Boniakowski, A.; Gallagher, K. Dysfunctional Wound Healing in Diabetic Foot Ulcers: New Crossroads Curr. Diab. Rep. 2018, 18, 2. [CrossRef]

4. Griffiths, C.E.M.; Armstrong, A.W.; Gudjonsson, J.E.; Barker, J.N.W.N. Psoriasis. Lancet 2021, 397, 1301-1315. [CrossRef]

5. Rendon, A.; Schäkel, K. Psoriasis pathogenesis and treatment. Int. J. Mol. Sci. 2019, 20, 1475. [CrossRef] [PubMed]

6. Edslev, S.M.; Agner, T.; Andersen, P.S. Skin microbiome in atopic dermatitis. Acta Derm. Venereol. 2020, 100, adv00164. [CrossRef] [PubMed]

7. Thapa, R.K.; Diep, D.B.; Tønnesen, H.H. Topical antimicrobial peptide formulations for wound healing: Current developments and future prospects. Acta Biomater. 2020, 103, 52-67. [CrossRef] [PubMed]

8. Jenssen, H.; Hancock, R.E.W. Therapeutic potential of HDPs as immunomodulatory agents. Methods Mol. Biol. 2010, 618, 329-347. [CrossRef] [PubMed]

9. Rivas-Santiago, B.; Rivas-Calderon, B.; Gonzalez-Curiel, I.; Montoya-Rosales, A.; Rincon, K.; Marin-Luevano, P.; DeHaro-Acosta J.; Lozano-Lopez, D.; Trujillo, V.; Enciso-Moreno, J.A. 1,25-Dihydroxyvitamin D3 Induces LL-37 and HBD-2 Production in Keratinocytes from Diabetic Foot Ulcers Promoting Wound Healing: An In Vitro Model. PLoS ONE 2014, 9, e111355. [CrossRef]

10. Jacobsen, A.S.; Jenssen, H. Human cathelicidin LL-37 prevents bacterial biofilm formation. Future Med. Chem. 2012, 4, 1587-1599. [CrossRef]

11. Magana, M.; Pushpanathan, M.; Santos, A.L.; Leanse, L.; Fernandez, M.; Ioannidis, A.; Giulianotti, M.A.; Apidianakis, Y.; Bradfute, S.; Ferguson, A.L.; et al. The value of antimicrobial peptides in the age of resistance. Lancet Infect. Dis. 2020, 20, E216-E230. [CrossRef]

12. He, X.; Yang, Y.; Mu, L.; Zhou, Y.; Chen, Y.; Wu, J.; Wang, Y.; Yang, H.; Li, M.; Xu, W.; et al. A Frog-Derived Immunomodulatory Peptide Promotes Cutaneous Wound Healing by Regulating Cellular Response. Front. Immunol. 2019, 10, 2421. [CrossRef]

13. Wang, G.; Li, X.; Wang, Z. APD3: The antimicrobial peptide database as a tool for research and education. Nucleic Acids Res. 2016, 44, 1087-1093. [CrossRef]

14. Jenssen, H.; Hamill, P.; Hancock, R.E.W. Peptide antimicrobial agents. Clin. Microbiol. Rev. 2006, 19, 491-511. [CrossRef]

15. Wieczorek, M.; Jenssen, H.; Kindrachuk, J.; Scott, W.R.P.; Elliott, M.; Hilpert, K.; Cheng, J.T.J.; Hancock, R.E.W.; Straus, S.K. Structural studies of a peptide with immune modulating and direct antimicrobial activity. Chem. Biol. 2010, 2, 970-980. [CrossRef]

16. Li, W.; Separovic, F.; O'Brien-Simpson, N.M.; Wade, J.D. Chemically modified and conjugated antimicrobial peptides against superbugs. Chem. Soc. Rev. 2021, 50, 4932-4973. [CrossRef]

17. Mojsoska, B.; Jenssen, H. Peptides and Peptidomimetics for Antimicrobial Drug Design. Pharmaceuticals 2015, 8, 366-415. [CrossRef] [PubMed]

18. Haney, E.F.; Straus, S.K.; Hancock, R.E.W. Reassessing the Host Defense Peptide Landscape. Front. Chem. 2019, 7, 43. [CrossRef] [PubMed]

19. Hamill, P.; Brown, K.; Jenssen, H.; Hancock, R.E.W. Novel anti-infectives: Is host defence the answer? Curr. Opin. Biotechnol. 2008, 19, 628-636. [CrossRef] [PubMed]

20. Pachón-Ibáñez, M.E.; Smani, Y.; Pachón, J.; Sánchez-Céspedes, J. Perspectives for clinical use of engineered human host defense antimicrobial peptides. FEMS Microbiol. Rev. 2017, 41, 323-342. [CrossRef] [PubMed]

21. Haney, E.F.; Hancock, R.E.W. Peptide design for antimicrobial and immunomodulatory applications. Biopolymers 2013, 100, 572-583. [CrossRef]

22. Rivas-Santiago, B.; Castañeda-Delgado, J.E.; Rivas Santiago, C.E.; Waldbrook, M.; González-Curiel, I.; León-Contreras, J.C.; Enciso-Moreno, J.A.; del Villar, V.; Mendez-Ramos, J.; Hancock, R.E.W.; et al. Ability of Innate Defence Regulator Peptides IDR-1002, IDR-HH2 and IDR-1018 to Protect against Mycobacterium tuberculosis Infections in Animal Models. PLoS ONE 2013, 8, e59119. [CrossRef]

23. Alencar-Silva, T.; Zonari, A.; Foyt, D.; Gang, M.; Pogue, R.; Saldanha-Araujo, F.; Dias, S.C.; Franco, O.L.; Carvalho, J.L. IDR-1018 induces cell proliferation, migration, and reparative gene expression in 2D culture and 3D human skin equivalents. J. Tissue Eng. Regen. Med. 2019, 13, 2018-2030. [CrossRef]

24. Steinstraesser, L.; Hirsch, T.; Schulte, M.; Kueckelhaus, M.; Jacobsen, F.; Mersch, E.A.; Stricker, I.; Afacan, N.; Jenssen, H.; Hancock, R.E.W.; et al. Innate defense regulator peptide 1018 in wound healing and wound infection. PLoS ONE 2012, 7, e39373. [CrossRef]

25. Otvos, L.; Ostorhazi, E. Therapeutic utility of antibacterial peptides in wound healing. Expert Rev. Anti. Infect. Ther. 2015, 13, 871-881. [CrossRef] 
26. Hancock, R.E.W.; Haney, E.F.; Gill, E.E. The immunology of host defence peptides: Beyond antimicrobial activity. Nat. Rev. Immunol. 2016, 16, 321-334. [CrossRef] [PubMed]

27. Campos, M.L.; De Souza, C.M.; De Oliveira, K.B.S.; Dias, S.C.; Franco, O.L. The role of antimicrobial peptides in plant immunity. J. Exp. Bot. 2018, 69, 4997-5011. [CrossRef] [PubMed]

28. Mylonakis, E.; Podsiadlowski, L.; Muhammed, M.; Vilcinskas, A. Diversity, evolution and medical applications of insect antimicrobial peptides. Philos. Trans. R. Soc. B Biol. Sci. 2016, 371, 20150290. [CrossRef] [PubMed]

29. Browne, K.; Chakraborty, S.; Chen, R.; Willcox, M.D.P.; Black, D.S.; Walsh, W.R.; Kumar, N. A new era of antibiotics: The clinical potential of antimicrobial peptides. Int. J. Mol. Sci. 2020, 21, 7047. [CrossRef]

30. Steinstraesser, L.; Koehler, T.; Jacobsen, F.; Daigeler, A.; Goertz, O.; Langer, S.; Kesting, M.; Steinau, H.; Eriksson, E.; Hirsch, T. Host defense peptides in wound healing. Mol. Med. 2008, 14, 528-537. [CrossRef]

31. Choi, H.; Kim, D.; Nam, S.; Lim, S.; Hwang, J.S.; Park, K.S.; Hong, H.S.; Won, Y.; Shin, M.K.; Chung, E.; et al. Substance P restores normal skin architecture and reduces epidermal infiltration of sensory nerve fiber in TNCB-induced atopic dermatitis-like lesions in NC/Nga mice. J. Dermatol. Sci. 2018, 89, 248-257. [CrossRef] [PubMed]

32. Zheng, Z.; Liu, Y.; Huang, W.; Mo, Y.; Lan, Y.; Guo, R.; Cheng, B. Neurotensin-loaded PLGA/CNC composite nanofiber membranes accelerate diabetic wound healing. Artif. Cells Nanomed. Biotechnol. 2018, 46, 493-501. [CrossRef] [PubMed]

33. Chung, W.H.; Hung, S.I.; Yang, J.Y.; Su, S.C.; Huang, S.P.; Wei, C.Y.; Chin, S.W.; Chiou, C.C.; Chu, S.C.; Ho, H.C.; et al. Granulysin is a key mediator for disseminated keratinocyte death in Stevens-Johnson syndrome and toxic epidermal necrolysis. Nat. Med. 2008, 14, 1343-1350. [CrossRef]

34. Ingram, J.R.; Cawley, S.; Coulman, E.; Gregory, C.; Thomas-Jones, E.; Pickles, T.; Cannings-John, R.; Francis, N.A.; Harding, K.; Hood, K.; et al. Levels of wound calprotectin and other inflammatory biomarkers aid in deciding which patients with a diabetic foot ulcer need antibiotic therapy (INDUCE study). Diabet. Med. 2018, 35, 255-261. [CrossRef]

35. Hans, M.; Madaan Hans, V. Epithelial antimicrobial peptides: Guardian of the oral cavity. Int. J. Pept. 2014, $2014,370297$. [CrossRef]

36. Croce, K.; Gao, H.; Wang, Y.; Mooroka, T.; Sakuma, M.; Shi, C.; Sukhova, G.K.; Packard, R.R.S.; Hogg, N.; Libby, P.; et al. Myeloid-related protein-8/14 is critical for the biological response to vascular injury. Circulation 2009, 120, 427-436. [CrossRef]

37. Rademacher, F.; Simanski, M.; Harder, J. RNase 7 in cutaneous defense. Int. J. Mol. Sci. 2016, 17, 560. [CrossRef]

38. Fruitwala, S.; El-Naccache, D.W.; Chang, T.L. Multifaceted immune functions of human defensins and underlying mechanisms. Semin. Cell Dev. Biol. 2019, 88, 163-172. [CrossRef]

39. Shafee, T.M.A.; Lay, F.T.; Phan, T.K.; Anderson, M.A.; Hulett, M.D. Convergent evolution of defensin sequence, structure and function. Cell. Mol. Life Sci. 2017, 74, 663-682. [CrossRef]

40. Howell, K.; de Leeuw, E. Cell adhesion properties of human defensins. Biochem. Biophys. Res. Commun. 2018, 502, $238-242$. [CrossRef] [PubMed]

41. Ottolini, B.; Hornsby, M.J.; Abujaber, R.; MacArthur, J.A.L.; Badge, R.M.; Schwarzacher, T.; Albertson, D.G.; Bevins, C.L.; Solnick, J.V.; Hollox, E.J. Evidence of convergent evolution in humans and macaques supports an adaptive role for copy number variation of the $\beta$-defensin-2 gene. Genome Biol. Evol. 2014, 6, 3025-3038. [CrossRef]

42. Ericksen, B.; Wu, Z.; Lu, W.; Lehrer, R.I. Antibacterial Activity and Specificity of Six Human Alpha-Defensins. Antimicrob. Agents Chemother. 2005, 49, 269-275. [CrossRef]

43. Basso, V.; Garcia, A.; Tran, D.Q.; Schaal, J.B.; Tran, P.; Ngole, D.; Aqeel, Y.; Tongaonkar, P.; Ouellette, A.J.; Selsteda, M.E. Fungicidal Potency and Mechanisms of $\theta$ - Defensins against Multidrug-Resistant Candida Species. Antimicrob. Agents Chemother. 2018, 62, e00111-18. [CrossRef]

44. Jenssen, H. Therapeutic approaches using host defence peptides to tackle herpes virus infections. Viruses 2009, 1, 939-964. [CrossRef]

45. Xu, D.; Lu, W. Defensins: A Double-Edged Sword in Host Immunity. Front. Immunol. 2020, 11, 764. [CrossRef]

46. Semple, F.; Dorin, J.R. $\beta$-Defensins: Multifunctional modulators of infection, inflammation and more? J. Innate Immun. 2012, 4, 337-348. [CrossRef]

47. Contreras, G.; Shirdel, I.; Braun, M.S.; Wink, M. Defensins: Transcriptional regulation and function beyond antimicrobial activity. Dev. Comp. Immunol. 2020, 104, 103556. [CrossRef] [PubMed]

48. van Harten, R.M.; van Woudenbergh, E.; van Dijk, A.; Haagsman, H.P. Cathelicidins: Immunomodulatory antimicrobials. Vaccines 2018, 6, 63. [CrossRef] [PubMed]

49. Engelberg, Y.; Landau, M. The Human LL-37(17-29) antimicrobial peptide reveals a functional supramolecular structure. Nat. Commun. 2020, 11, 3894. [CrossRef] [PubMed]

50. Chen, J.; Zhai, Z.; Long, H.; Yang, G.; Deng, B.; Deng, J. Inducible expression of defensins and cathelicidins by nutrients and associated regulatory mechanisms. Peptides 2020, 123, 170177. [CrossRef] [PubMed]

51. Podaza, E.; Palacios, F.; Croci, D.O.; Risnik, D.; Yan, X.J.; Almejún, M.B.; Colado, A.; Elías, E.E.; Borge, M.; Morande, P.E.; et al. Expression and function of cathelicidin hCAP18/LL-37 in chronic lymphocytic leukemia. Haematologica 2020, 105, e465-e469. [CrossRef]

52. Khurshid, Z.; Naseem, M.; Asiri, F.Y.I.; Mali, M.; Khan, R.S.; Sahibzada, H.A.; Zafar, M.S.; Moin, S.F.; Khan, E. Significance and diagnostic role of antimicrobial cathelicidins (L1-37) peptides in oral health. Biomolecules 2017, 7, 80. [CrossRef] 
53. Scheenstra, M.R.; van Harten, R.M.; Veldhuizen, E.J.A.; Haagsman, H.P.; Coorens, M. Cathelicidins Modulate TLR-Activation and Inflammation. Front. Immunol. 2020, 11, 1137. [CrossRef]

54. Coorens, M.; Scheenstra, M.R.; Veldhuizen, E.J.A.; Haagsman, H.P. Interspecies cathelicidin comparison reveals divergence in antimicrobial activity, TLR modulation, chemokine induction and regulation of phagocytosis. Sci. Rep. 2017, 7, 40874. [CrossRef] [PubMed]

55. Tripathi, S.; Wang, G.; White, M.; Qi, L.; Taubenberger, J.; Hartshorn, K.L. Antiviral activity of the human cathelicidin, LL-37, and derived peptides on seasonal and pandemic influenza A viruses. PLoS ONE 2015, 10, e0124706. [CrossRef] [PubMed]

56. Van Eijk, M.; Boerefijn, S.; Cen, L.; Rosa, M.; Morren, M.J.H.; Van Der Ent, C.K.; Kraak, B.; Dijksterhuis, J.; Valdes, I.D.; Haagsman, H.P.; et al. Cathelicidin-inspired antimicrobial peptides as novel antifungal compounds. Med. Mycol. 2020, 58, 1073-1084. [CrossRef]

57. Maranduca, M.; Hurjui, L.; Branisteanu, D.; Serban, D.; Branisteanu, D.; Dima, N.; Serban, I. Skin-A vast organ with immunological function (Review). Exp. Ther. Med. 2020, 20, 18-23. [CrossRef] [PubMed]

58. Bird, J.A.; Sánchez-Borges, M.; Ansotegui, I.J.; Ebisawa, M.; Martell, J.A.O. Skin as an immune organ and clinical applications of skin-based immunotherapy. World Allergy Organ. J. 2018, 144, 362-374. [CrossRef]

59. Sorg, H.; Tilkorn, D.J.; Hager, S.; Hauser, J.; Mirastschijski, U. Skin Wound Healing: An Update on the Current Knowledge and Concepts. Eur. Surg. Res. 2017, 58, 81-94. [CrossRef] [PubMed]

60. Dangwal, S.; Stratmann, B.; Bang, C.; Lorenzen, J.M.; Kumarswamy, R.; Fiedler, J.; Falk, C.S.; Scholz, C.J.; Thum, T.; Tschoepe, D. Impairment of Wound Healing in Patients with Type 2 Diabetes Mellitus Influences Circulating MicroRNA Patterns via Inflammatory Cytokines. Arterioscler. Thromb. Vasc. Biol. 2015, 35, 1480-1488. [CrossRef]

61. Ellis, S.; Lin, E.J.; Tartar, D. Immunology of Wound Healing. Curr. Dermatol. Rep. 2018, 7, 350-358. [CrossRef]

62. Wilkinson, H.N.; Hardman, M.J. Wound healing: Cellular mechanisms and pathological outcomes: Cellular Mechanisms of Wound Repair. Open Biol. 2020, 10, 200223. [CrossRef] [PubMed]

63. Futosi, K.; Fodor, S.; Mócsai, A. Neutrophil cell surface receptors and their intracellular signal transduction pathways. Int. Immunopharmacol. 2013, 17, 638-650. [CrossRef] [PubMed]

64. Zhao, R.; Liang, H.; Clarke, E.; Jackson, C.; Xue, M. Inflammation in chronic wounds. Int. J. Mol. Sci. 2016, 17, 2085. [CrossRef] [PubMed]

65. Koh, T.J.; DiPietro, L.A. Inflammation and wound healing: The role of the macrophage. Expert Rev. Mol. Med. 2011, 13, e23. [CrossRef]

66. Wang, N.; Liang, H.; Zen, K. Molecular mechanisms that influence the macrophage M1-M2 polarization balance. Front. Immunol. 2014, 5, 1-9. [CrossRef]

67. Midwood, K.S.; Williams, L.V.; Schwarzbauer, J.E. Tissue repair and the dynamics of the extracellular matrix. Int. J. Biochem. Cell Biol. 2004, 36, 1031-1037. [CrossRef]

68. Ilina, O.; Friedl, P. Mechanisms of collective cell migration at a glance. J. Cell Sci. 2009, 122, 3203-3208. [CrossRef]

69. Betz, C.; Lenard, A.; Belting, H.-G.; Affolter, M. Cell behaviors and dynamics during angiogenesis. Development 2016, 143, 2249-2260. [CrossRef]

70. Tracy, L.E.; Minasian, R.A.; Caterson, E.J. Extracellular Matrix and Dermal Fibroblast Function in the Healing Wound. Adv. Wound Care 2016, 5, 119-136. [CrossRef]

71. Velnar, T.; Bailey, T. The Wound Healing Process: An Overview of the Cellular and Molecular Mechanisms. J. Int. Med. Res. 2009, 37, 1528-1542. [CrossRef] [PubMed]

72. Darby, I.A.; Laverdet, B.; Bonté, F.; Desmoulière, A. Fibroblasts and myofibroblasts in wound healing. Clin. Cosmet. Investig. Dermatol. 2014, 7, 301-311. [CrossRef]

73. de Oliveira Gonzalez, A.C.; Costa, T.F.; de Araújo Andrade, Z.; Medrado, A.R.A.P. Wound healing-A literature review. An. Bras. Dermatol. 2016, 91, 614-620. [CrossRef]

74. Hinz, B.; Gabbiani, G. Cell-matrix and cell-cell contacts of myofibroblasts: Role in connective tissue remodeling. Thromb. Haemost. 2003, 90, 993-1002. [CrossRef]

75. Di Pietro, L.A. Angiogenesis and scar formation in healing wounds. Curr. Opin. Rheumatol. 2013, 25, 87-91. [CrossRef] [PubMed]

76. Gabbiani, G. The myofibroblast in wound healing and fibrocontractive diseases. J. Pathol. 2003, 200, 500-503. [CrossRef] [PubMed]

77. Xue, M.; Jackson, C.J. Extracellular Matrix Reorganization During Wound Healing and Its Impact on Abnormal Scarring. Adv. Wound Care 2015, 4, 119-136. [CrossRef] [PubMed]

78. Guo, S.; DiPietrio, L. Factors Affecting Wound Healing. J. Dent. Res. 2010, 89, 219-229. [CrossRef] [PubMed]

79. Frykberg, R.G.; Banks, J. Challenges in the Treatment of Chronic Wounds. Adv. Wound Care 2015, 4, 560-582. [CrossRef]

80. Capparelli, R.; De Chiara, F.; Nocerino, N.; Montella, R.C.; Iannaccone, M.; Fulgione, A.; Romanelli, A.; Avitabile, C.; Blaiotta, G.; Capuano, F. New perspectives for natural antimicrobial peptides: Application as antinflammatory drugs in a murine model. BMC Immunol. 2012, 13, 61. [CrossRef]

81. Scott, M.G.; Dullaghan, E.; Mookherjee, N.; Glavas, N.; Waldbrook, M.; Thompson, A.; Wang, A.; Lee, K.; Doria, S.; Hamill, P.; et al. An anti-infective peptide that selectively modulates the innate immune response. Nat. Biotechnol. 2007, 25, 465-472. [CrossRef]

82. Wiegand, C.; Schönfelder, U.; Abel, M.; Ruth, P.; Kaatz, M.; Hipler, U.C. Protease and pro-inflammatory cytokine concentrations are elevated in chronic compared to acute wounds and can be modulated by collagen type i in vitro. Arch. Dermatol. Res. 2010, 302, 419-428. [CrossRef] 
83. Koczulla, R.; Bals, R. Cathelicidin Antimicrobial Peptides Modulate Angiogenesis. In Therapeutic Neovascularization-Quo Vadis? Deindl, E., Kupatt, C., Eds.; Springer: Dordrecht, The Netherlands, 2007; pp. 191-196. [CrossRef]

84. Choi, K.Y.; Chow, L.N.Y.; Mookherjee, N. Cationic host defence peptides: Multifaceted role in immune modulation and inflammation. J. Innate Immun. 2012, 4, 361-370. [CrossRef]

85. Huang, H.J.; Ross, C.R.; Blecha, F. Chemoattractant properties of PR-39, a neutrophil antibacterial peptide. J. Leukoc. Biol. 1997, 61, 624-629. [CrossRef]

86. Welkos, S.; Cote, C.K.; Hahn, U.; Shastak, O.; Jedermann, J.; Bozue, J.; Jung, G.; Ruchala, P.; Pratikhya, P.; Tang, T.; et al. Humanized $\theta$-defensins (retrocyclins) enhance macrophage performance and protect mice from experimental anthrax infections. Antimicrob. Agents Chemother. 2011, 55, 4238-4250. [CrossRef]

87. Tokumaru, S.; Sayama, K.; Shirakata, Y.; Komatsuzawa, H.; Ouhara, K.; Hanakawa, Y.; Yahata, Y.; Dai, X.; Tohyama, M.; Nagai, H.; et al. Induction of Keratinocyte Migration via Transactivation of the Epidermal Growth Factor Receptor by the Antimicrobial Peptide LL-37. J. Immunol. 2005, 175, 4662-4668. [CrossRef] [PubMed]

88. Kim, S.-H.; Kim, Y.N.; Jang, Y.-S. Cutting Edge: LL-37-Mediated Formyl Peptide Receptor-2 Signaling in Follicular Dendritic Cells Contributes to B Cell Activation in Peyer's Patch Germinal Centers. J. Immunol. 2017, 206, 1600886. [CrossRef] [PubMed]

89. Hemshekhar, M.; Choi, K.Y.G.; Mookherjee, N. Host defense peptide LL-37-mediated chemoattractant properties, but not anti-inflammatory cytokine IL-1RA production, is selectively controlled by Cdc42 Rho GTPase via G protein-coupled receptors and JNK mitogen-activated protein kinase. Front. Immunol. 2018, 9, 1871. [CrossRef] [PubMed]

90. Minns, D.; Smith, K.J.; Alessandrini, V.; Hardisty, G.; Melrose, L.; Jackson-Jones, L.; MacDonald, A.S.; Davidson, D.J.; Gwyer Findlay, E. The neutrophil antimicrobial peptide cathelicidin promotes Th17 differentiation. Nat. Commun. 2021, $12,1285$. [CrossRef] [PubMed]

91. Niyonsaba, F.; Ushio, H.; Nagaoka, I.; Okumura, K.; Ogawa, H. The Human $\beta$-Defensins (-1, -2, -3, -4) and Cathelicidin LL37 Induce IL-18 Secretion through p38 and ERK MAPK Activation in Primary Human Keratinocytes. J. Immunol. 2005, 175, 1776-1784. [CrossRef]

92. Lande, R.; Chamilos, G.; Ganguly, D.; Demaria, O.; Frasca, L.; Durr, S.; Conrad, C.; Schröder, J.; Gilliet, M. Cationic antimicrobial peptides in psoriatic skin cooperate to break innate tolerance to self-DNA. Eur. J. Immunol. 2015, 45, 203-213. [CrossRef] [PubMed]

93. Bhatt, T.; Bhosale, A.; Bajantri, B.; Mathapathi, M.S.; Rizvi, A.; Scita, G.; Majumdar, A.; Jamora, C. Sustained Secretion of the Antimicrobial Peptide S100A7 Is Dependent on the Downregulation of Caspase-8. Cell Rep. 2019, 29, 2546-2555.e4. [CrossRef]

94. Koczulla, R.; Von Degenfeld, G.; Kupatt, C.; Krötz, F.; Zahler, S.; Gloe, T.; Issbrücker, K.; Unterberger, P.; Zaiou, M.; Lebherz, C.; et al. An angiogenic role for the human peptide antibiotic LL-37/hCAP-18. J. Clin. Invest. 2003, 111, 1665-1672. [CrossRef]

95. Raziyeva, K.; Kim, Y.; Zharkinbekov, Z.; Kassymbek, K.; Jimi, S.; Saparov, A. Immunology of acute and chronic wound healing. Biomolecules 2021, 11, 700. [CrossRef]

96. Chen, S.; Lu, Z.; Wang, F.; Wang, Y. Cathelicidin-WA polarizes E. coli K88-induced M1 macrophage to M2-like macrophage in RAW264.7 cells. Int. Immunopharmacol. 2018, 54, 52-59. [CrossRef]

97. Gauglitz, G.G.; Bureik, D.; Zwicker, S.; Ruzicka, T.; Wolf, R. The antimicrobial peptides psoriasin (s100a7) and koebnerisin (S100A15) suppress extracellular matrix production and proliferation of human fibroblasts. Skin Pharmacol. Physiol. 2015, 28, 115-123. [CrossRef] [PubMed]

98. Hilchie, A.L.; Wuerth, K.; Hancock, R.E. Immune modulation by multifaceted cationic host. Nat. Chem. Biol. 2013, 9, 761-768. [CrossRef] [PubMed]

99. Kwiecien, K.; Zegar, A.; Jung, J.; Brzoza, P.; Kwitniewski, M.; Godlewska, U.; Grygier, B.; Kwiecinska, P.; Morytko, A.; Cichy, J. Architecture of antimicrobial skin defense. Cytokine Growth Factor Rev. 2019, 49, 70-84. [CrossRef] [PubMed]

100. Marcinkiewicz, M.; Majewski, S. The role of antimicrobial peptides in chronic inflammatory skin diseases. Postep. Dermatol. Alergol. 2016, 33, 6-12. [CrossRef]

101. Versey, Z.; da Cruz Nizer, W.S.; Russell, E.; Zigic, S.; DeZeeuw, K.G.; Marek, J.E.; Overhage, J.; Cassol, E. Biofilm-Innate Immune Interface: Contribution to Chronic Wound Formation. Front. Immunol. 2021, 12, 648554. [CrossRef]

102. Pereira, L.; Neves, B.M.; Moura, L.; Cruz, M.T.; Carvalho, E. Neurotensin Decreases the Proinflammatory Status of Human Skin Fibroblasts and Increases Epidermal Growth Factor Expression. Int. J. Inflam. 2014, 2014, 248240. [CrossRef]

103. Turner-Brannen, E.; Choi, K.Y.; Lippert, D.N.D.; Cortens, J.P.; Hancock, R.E.W.; El-Gabalawy, H.; Mookherjee, N. Modulation of interleukin-1 $\beta$-induced inflammatory responses by a synthetic cationic innate defence regulator peptide, IDR-1002, in synovial fibroblasts. Arthritis Res. Ther. 2011, 13, R129. [CrossRef] [PubMed]

104. Mookherjee, N.; Hamill, P.; Gardy, J.; Blimkie, D.; Falsafi, R.; Chikatamarla, A.; Arenillas, D.J.; Doria, S.; Kollmann, T.R.; Hancock, R.E.W. Systems biology evaluation of immune responses induced by human host defence peptide LL-37 in mononuclear cells. Mol. Biosyst. 2009, 5, 483-496. [CrossRef] [PubMed]

105. Nijnik, A.; Madera, L.; Ma, S.; Waldbrook, M.; Elliott, M.R.; Easton, D.M.; Mayer, M.L.; Mullaly, S.C.; Kindrachuk, J.; Jenssen, H.; et al. Synthetic cationic peptide IDR-1002 provides protection against bacterial infections through chemokine induction and enhanced leukocyte recruitment. J. Immunol. 2010, 184, 2539-2550. [CrossRef]

106. Casqueiro, J.; Casqueiro, J.; Alves, C. Infections in patients with diabetes mellitus: A review of pathogenesis. Indian J. Endocrinol. Metab. 2012, 16 (Suppl. 1), S27-S36. [CrossRef]

107. Prasad, S.V.; Fiedoruk, K.; Daniluk, T.; Piktel, E.; Bucki, R. Expression and function of host defense peptides at inflammation sites. Int. J. Mol. Sci. 2020, 21, 104. [CrossRef] 
108. Kolbinger, F.; Loesche, C.; Valentin, M.-A.; Jiang, X.; Cheng, Y.; Jarvis, P.; Peters, T.; Calonder, C.; Bruin, G.; Polus, F.; et al. $\beta$-Defensin 2 is a responsive biomarker of IL-17A-driven skin pathology in patients with psoriasis. J. Allergy Clin. Immunol. 2017, 139, 923-932.e8. [CrossRef]

109. Kim, B.E.; Leung, D.Y.M. Significance of skin barrier dysfunction in atopic dermatitis. Allergy Asthma Immunol. Res. 2018, 10, 207-215. [CrossRef]

110. Nguyen, H.L.T.; Trujillo-Paez, J.V.; Umehara, Y.; Yue, H.; Peng, G.; Kiatsurayanon, C.; Chieosilapatham, P.; Song, P.; Okumura, K.; Ogawa, H.; et al. Role of antimicrobial peptides in skin barrier repair in individuals with atopic dermatitis. Int. J. Mol. Sci. 2020, 21, 7607. [CrossRef]

111. Mookherjee, N.; Hancock, R.E.W. Cationic host defence peptides: Innate immune regulatory peptides as a novel approach for treating infections. Cell. Mol. Life Sci. 2007, 64, 922-933. [CrossRef] [PubMed]

112. Macleod, A.S.; Mansbridge, J.N. The Innate Immune System in Acute and Chronic Wounds. Adv. Wound Care 2015, 5, 65-78. [CrossRef]

113. Lima, M.H.M.; Caricilli, A.M.; de Abreu, L.L.; Araújo, E.P.; Pelegrinelli, F.F.; Thirone, A.C.P.; Tsukumo, D.M.; Pessoa, A.F.M.; dos Santos, M.F.; de Moraes, M.A.; et al. Topical insulin accelerates wound healing in diabetes by enhancing the AKT and ERK pathways: A double-blind placebo-controlled clinical trial. PLoS ONE 2012, 7, e36974. [CrossRef]

114. Gao, L.C.; Li, T.T.; Li, F.Y.; Tang, L.; Li, H.Y.; Wang, X.J.; Li, X.K. Role of ERK-1/2 signaling pathway in keratinacyte growth factor-2 stimulating human keratinocyte proliferation. Chin. Pharmacol. Bull. 2011, 27, 1405-1408. [CrossRef]

115. Yoon, S.; Seger, R. The extracellular signal-regulated kinase: Multiple substrates regulate diverse cellular functions. Growth Factors 2006, 24, 21-44. [CrossRef] [PubMed]

116. Somanath, P.R.; Chen, J.; Byzova, T.V. Akt1 is necessary for the vascular maturation and angiogenesis during cutaneous wound healing. Angiogenesis 2008, 11, 277-288. [CrossRef]

117. Mouritzen, M.V.; Carvalho, E.; Abourayale, S.; Ejaz, R.; Ardon, C.B.; Roursgaard, M.; Dalgaard, L.T. Neurotensin, substance P, and insulin enhance cell migration. J. Pept. Sci. 2018, 24, e3093. [CrossRef] [PubMed]

118. Hesketh, M.; Sahin, K.B.; West, Z.E.; Murray, R.Z. Macrophage phenotypes regulate scar formation and chronic wound healing. Int. J. Mol. Sci. 2017, 18, 1545. [CrossRef] [PubMed]

119. Krzyszczyk, P.; Schloss, R.; Palmer, A.; Berthiaume, F. The role of macrophages in acute and chronic wound healing and interventions to promote pro-wound healing phenotypes. Front. Physiol. 2018, 9, 419. [CrossRef] [PubMed]

120. Saporito, P.; Mouritzen, M.V.; Løbner-Olesen, A.; Jenssen, H. LL-37 fragments have antimicrobial activity against Staphylococcus epidermidis biofilms and wound healing potential in HaCaT cell line. J. Pept. Sci. 2018, 24, e3080. [CrossRef] [PubMed]

121. Mouritzen, M.V.; Andrea, A.; Qvist, K.; Poulsen, S.S.; Jenssen, H. Immunomodulatory potential of Nisin A with application in wound healing. Wound Repair Regen. 2019, 27, 650-660. [CrossRef]

122. Mansour, S.C.; De La Fuente-Núñez, C.; Hancock, R.E.W. Peptide IDR-1018: Modulating the immune system and targeting bacterial biofilms to treat antibiotic-resistant bacterial infections. J. Pept. Sci. 2015, 21, 323-329. [CrossRef]

123. Mouritzen, M.V.; Petkovic, M.; Qvist, K.; Poulsen, S.S.; Alarico, S.; Leal, E.C.; Dalgaard, L.T.; Empadinhas, N.; Carvalho, E.; Jenssen, H. Improved diabetic wound healing by LFcinB is associated with relevant changes in the skin immune response and microbiota. Mol. Ther. Methods Clin. Dev. 2021, 20, 726-739. [CrossRef] [PubMed]

124. Jin, Y.; Yang, Y.; Duan, W.; Qu, X.; Wu, J. Synergistic and On-Demand Release of Ag-AMPs Loaded on Porous Silicon Nanocarriers for Antibacteria and Wound Healing. ACS Appl. Mater. Interfaces 2021, 13, 16127-16141. [CrossRef] [PubMed]

125. Jiang, J.; Chen, S.; Wang, H.; Carlson, M.A.; Gombart, A.F.; Xie, J. CO2-expanded nanofiber scaffolds maintain activity of encapsulated bioactive materials and promote cellular infiltration and positive host response. Acta Biomater. 2018, 68, 237-248. [CrossRef] [PubMed]

126. Garcia-Orue, I.; Gainza, G.; Girbau, C.; Alonso, R.; Aguirre, J.J.; Pedraz, J.L.; Igartua, M.; Hernandez, R.M. LL37 loaded nanostructured lipid carriers (NLC): A new strategy for the topical treatment of chronic wounds. Eur. J. Pharm. Biopharm. 2016, 108, 310-316. [CrossRef] [PubMed]

127. Chereddy, K.K.; Her, C.H.; Comune, M.; Moia, C.; Lopes, A.; Porporato, P.E.; Vanacker, J.; Lam, M.C.; Steinstraesser, L.; Sonveaux, P.; et al. PLGA nanoparticles loaded with host defense peptide LL37 promote wound healing. J. Control. Release 2014, 194, 138-147. [CrossRef] [PubMed]

128. Wang, S.; Yan, C.; Zhang, X.; Shi, D.; Chi, L.; Luo, G.; Deng, J. Antimicrobial peptide modification enhances the gene delivery and bactericidal efficiency of gold nanoparticles for accelerating diabetic wound healing. Biomater. Sci. 2018, 6, 2757-2772. [CrossRef] [PubMed]

129. Tsikourkitoudi, V.; Karlsson, J.; Merkl, P.; Loh, E.; Henriques-Normark, B.; Sotiriou, G.A. Flame-made calcium phosphate nanoparticles with high drug loading for delivery of biologics. Molecules 2020, 25, 1747. [CrossRef]

130. Luo, G.; Sun, Y.; Zhang, J.; Xu, Z.; Lu, W.; Wang, H.; Zhang, Y.; Li, H.; Mao, Z.; Ye, S.; et al. Nanodefensin-encased hydrogel with dual bactericidal and pro-regenerative functions for advanced wound therapy. Theranostics 2021, 11, 3642-3660. [CrossRef]

131. Comune, M.; Rai, A.; Chereddy, K.K.; Pinto, S.; Aday, S.; Ferreira, A.F.; Zonari, A.; Blersch, J.; Cunha, R.; Rodrigues, R.; et al. Antimicrobial peptide-gold nanoscale therapeutic formulation with high skin regenerative potential. J. Control. Release 2017, 262, 58-71. [CrossRef] [PubMed] 
132. Moura, L.I.F.; Dias, A.M.A.; Suesca, E.; Casadiegos, S.; Leal, E.C.; Fontanilla, M.R.; Carvalho, L.; de Sousa, H.C.; Carvalho, E. Neurotensin-loaded collagen dressings reduce inflammation and improve wound healing in diabetic mice. Biochim. Biophys. Acta Mol. Basis Dis. 2014, 1842, 32-43. [CrossRef]

133. Moura, L.I.; Cruz, M.T.; Carvalho, E. The effect of neurotensin in human keratinocytes-implication on impaired wound healing in diabetes. Exp. Biol. Med. 2014, 239, 6-12. [CrossRef] [PubMed]

134. Sandoval-Talamantes, A.K.; Gómez-González, B.A.; Uriarte-Mayorga, D.F.; Martínez-Guzman, M.A.; Wheber-Hidalgo, K.A.; Alvarado-Navarro, A. Neurotransmitters, neuropeptides and their receptors interact with immune response in healthy and psoriatic skin. Neuropeptides 2020, 79, 102004. [CrossRef] [PubMed]

135. Leal, E.C.; Carvalho, E.; Tellechea, A.; Kafanas, A.; Tecilazich, F.; Kearney, C.; Kuchibhotla, S.; Auster, M.E.; Kokkotou, E.; Mooney, D.J.; et al. Substance P promotes wound healing in diabetes by modulating inflammation and macrophage phenotype. Am. J. Pathol. 2015, 185, 1638-1648. [CrossRef] [PubMed]

136. De Serres-Bérard, T.; Becher, T.B.; Braga, C.B.; Ornelas, C.; Berthod, F. Neuropeptide Substance P Released from a Nonswellable Laponite-Based Hydrogel Enhances Wound Healing in a Tissue-Engineered Skin in Vitro. ACS Appl. Polym. Mater. 2020, 2, 5790-5797. [CrossRef] 